\title{
Commentary
}

Molecular

Neuropsychiatry
Mol Neuropsychiatry 2018;4:83-89

DOI: $10.1159 / 000491489$
Received: March 12, 2018

Accepted: June 22, 2018

Published online: August 20, 2018

\section{The Sex Chromosome Hypothesis of Schizophrenia: Alive, Dead, or Forgotten? A Commentary and Review}

\author{
William K. Bache ${ }^{a, b}$ Lynn E. DeLisia ${ }^{a, c}$ \\ ${ }^{a}$ VA Boston Healthcare System, Brockton, MA, USA; b Harvard South Shore Residency Program, Brockton, MA, USA; \\ 'Department of Psychiatry, Harvard Medical School, Boston, MA, USA
}

\section{Keywords}

X chromosome · Schizophrenia - Genetics · Genes .

Psychosis

\begin{abstract}
The $\mathrm{X}$ chromosome has long been an intriguing site for harboring genes that have importance in brain development and function. It has received the most attention for having specific genes underlying the $X$-linked inherited intellectual disabilities, but has also been associated with schizophrenia in a number of early studies. An X chromosome hypothesis for a genetic predisposition for schizophrenia initially came from the $X$ chromosome anomaly population data showing an excess of schizophrenia in Klinefelter's (XXY) males and triple X (XXX) females. Crow and colleagues later expanded the $X$ chromosome hypothesis to include the possibility of a locus on the $Y$ chromosome and, specifically, genes on $X$ that escaped inactivation and are $X-Y$ homologous loci. Some new information about possible risk loci on these chromosomes has come from the current large genetic consortia genome-wide association studies, suggesting that perhaps this hypothesis needs to be revisited for some schizophrenias. The following commentary reviews the early and more
\end{abstract}

recent literature supporting or refuting this dormant hypothesis and emphasizes the possible candidate genes still of interest that could be explored in further studies.

(c) 2018 S. Karger AG, Basel

\section{Introduction}

Several years ago, the literature was populated with reports that sex chromosome anomalies were more frequent in people with schizophrenia, and case reports were published, particularly on X chromosome anomalies and schizophrenia [1-3]. These were published in years prior to the field having the technology for examining DNA sequences and genes directly. The main source of genetic data came from chromosome karyotypes and, particularly, some high-resolution ones. However, the early large population studies specifically screening for $\mathrm{X}$ chromosomes were reports based on buccal smear findings of the so-called "bar bodies" in cells indicating extra X chromosomes (e.g., more than 1 ; [4-7]). It was generally recognized that having Klinefelter's syndrome put one at an increased risk for a major psychiatric disorder, particularly psychotic in nature $[2,8]$.

\section{KARGER}

(c) 2018 S. Karger AG, Basel

E-Mail karger@karger.com

www.karger.com/mnp 
At the same time, observations also existed of many sex differences in the clinical aspects of schizophrenia, such as the timing of onset, specific symptom clusters, and outcome of the disorder (reviewed in [9-12]), as well as sex differences in familial risk for schizophrenia (reviewed in [13]). The combination of these 2 lines of evidence led DeLisi and Crow in a series of papers in the 1980s and 1990s to postulate that a gene for schizophrenia must exist on the sex chromosomes, not just on $\mathrm{X}$ but also on $\mathrm{Y}[3,14-17]$. Since the illness was transmitted to females and males from both mothers and fathers and, thus, did not follow the typical X-linked pattern of inheritance, the hypothesis led to emphasizing the regions of homology between both $\mathrm{X}$ and $\mathrm{Y}$ and also loci where recombination between $\mathrm{X}$ and $\mathrm{Y}$ chromosomes is known to occur $[3,14]$ (reviewed in [18]). The hypothesis was further supported by the observations that many genes expressed in the brain responsible for cognitive development are derived from the $\mathrm{X}$ chromosome and that approximately $50 \%$ of all intellectual disabilities have a defect in a gene on the $\mathrm{X}$ chromosome as its underlying basis (reviewed in $[19,20])$.

Nevertheless, although initially promising [21-23], early molecular studies were never able to show a linkage or association with schizophrenia for any region of the sex chromosomes or variants in the genes located there, despite the existence of some good candidates [24-31]. Although there continued to be lack of data to support this hypothesis and interest waned among most investigators in pursuing it further, the sex chromosome hypothesis has never been clearly negated. Gene expression on the sex chromosomes is difficult to study because of the complexity of $\mathrm{X}$ inactivation, its possible skewness in some situations, the various genes that escape inactivation fully or at least partially, and finally the fact that inactivation of $\mathrm{X}$ chromosome genes may be occurring in some cells but not others. Given these problems, knowledge is limited about the most appropriate ways in which population data on sex chromosome genes can be evaluated. Nevertheless, there are some indications that factors on these chromosomes do confer at minimum a small risk $[32,33]$.

Goldstein and colleagues [4] recently published a review of sex differences in the genetics of schizophrenia and also described a study from their group [34] which demonstrated that psychosis rates for offspring of ill individuals were similar when sex of the progeny was not considered. But, if the sex of both the ill parent and the affected offspring were taken into account, then a sexdependent pattern of transmission appeared. Sons of mothers with psychosis had a higher rate of illness than daughters of women with the disorder (18.8 vs. 9.5\%). Additionally, daughters of men with psychosis had an increased incidence of psychosis when compared to male progeny of other psychotic males (15.2 vs. 3.2\%; Goldstein et al. [34]). These results, along with a review of other studies involving both schizophrenia and bipolar disorder, led these authors to suggest that a sex chromosome gene for psychosis still remains viable and that reduced penetrance or $\mathrm{X}$ inactivation may be occurring when mothers transmit the $\mathrm{X}$ chromosome gene to daughters. In the case of transmission from fathers, these authors suggest that an $\mathrm{X}$ chromosome gene is more likely involved than one on $\mathrm{Y}$, given excess father-to-daughter transmission. This study contrasts with the much earlier report of Crow et al. [14] finding evidence for $\mathrm{X}$ and $Y$ inheritance for schizophrenia from family data of multiplex families with affected sibling pairs. In these families, those individuals who had paternal inheritance of illness were more likely to be siblings of the same sex than those affected siblings with a maternal line of inheritance of illness. Since fathers pass on their X to daughters and their $\mathrm{Y}$ to sons, if the gene for illness were on either $\mathrm{X}$ or $\mathrm{Y}$, it is likely that those siblings affected would be the same sex. Whereas, since mothers pass on 1 of their $2 \mathrm{Xs}$ to their children (sons or daughters), it would be unlikely that with maternal inheritance, same-sex concordance would occur any more than by chance. Nevertheless, this study may not be inconsistent with the Goldstein et al. [34] report, since it did not address whether fathers transmitted illness more often to daughters than sons. Neither of these studies has yet been replicated in other populations.

\section{The Candidate Gene Approach}

Examples of candidate sex chromosome genes that have specifically been studied and implicated in schizophrenia are currently weak and inconsistent. These are listed in Table 1.

1. The MAOB (monoamine oxidase B gene) located on $\mathrm{Xp} 11$, which is associated with deamination of certain amines in food along with neurotransmitters, including dopamine. Studies have shown a male-specific haplotype associated with psychosis and polymorphisms that have been associated with psychotic symptoms, such as delusions [35-38].

2. The protocadherin $11 \mathrm{X}$ and $\mathrm{Y}$ (PCDH11XY) gene pair. Crow (reviewed in $[18,39]$ ) hypothesized in- 
Table 1. Summary of loci on the sex chromosomes found to be candidates or genes of interest for increased risk of schizophrenia

\begin{tabular}{|c|c|c|}
\hline Locus & $\begin{array}{l}\text { Chromosomal } \\
\text { location }\end{array}$ & Known function \\
\hline $\mathrm{CNKSR}^{\mathrm{a}}$ & $\mathrm{Xp} 22.12$ & $\begin{array}{l}\text { A scaffolding protein. Plays a role in assembling synaptic complexes. Loss of function is associated } \\
\text { with X-linked mental disability [33]. }\end{array}$ \\
\hline NLGN4X ${ }^{\mathrm{a}}$ & Xp21.33-32 & $\begin{array}{l}\text { A neuroligin, may modulate the presynaptic calcium channel by interaction with neurexins. } \\
\text { Mutations found in autism [33]. }\end{array}$ \\
\hline $\mathrm{DMD}^{\mathrm{c}}$ & $\mathrm{Xp} 21.2$ & $\begin{array}{l}\text { Connects the cytoskeleton of skeletal muscle to the basal lamina. Loss leads to dysfunction in } \\
\text { mitochondrial permeability, and subsequent increase of stress-induced reactive oxygen species } \\
\text { leads to damage and cell death [64]. }\end{array}$ \\
\hline MAOB & Xp11.3 & $\begin{array}{l}\text { Produces enzyme involved in oxidation of monoamines including 5-HT and DA as well as other } \\
\text { neuro- and vasoactive amines in the central nervous system [65]. }\end{array}$ \\
\hline KDM5C $C^{b}$ & Xp11.22 & $\begin{array}{l}\text { Involved in encoding a chromatin-modifying enzyme that acts on the amino acid on histone } \mathrm{H} 3 \text {. } \\
\text { Mutations in histone } \mathrm{H} 3 \text { methylation have been shown to be involved in several disorders of } \\
\text { intellectual disability. Additionally, it has been found to be involved in the transcription of genes } \\
\text { related to neural plasticity and neural maturation [66]. }\end{array}$ \\
\hline $\begin{array}{l}\text { SYP/ } \\
\text { CACNA1F }\end{array}$ & Xp11 & $\begin{array}{l}\text { SYP: Encodes a membrane protein of small synaptic vesicles in brain and endocrine cells. Involved } \\
\text { in early neurogenesis and synaptogenesis. Also involved in the regulation of neurotransmitter } \\
\text { release, synaptoplasticity, and production/recycling of vesicles in synapses [67]. } \\
\text { CACNA1F: Involved in the production of Ca channels. In particular, this gene provides } \\
\text { instructions on making a portion of the alpha subunit for these channels }[68,69] \text {. }\end{array}$ \\
\hline HOPA & $\mathrm{Xq13}$ & $\begin{array}{l}\text { Belongs to the thyroid receptor-associated proteins (TRAP) that serve as co-activators for thyroid } \\
\text { hormone receptor. Also codes proteins critical in the regulation of transcription via the Wnt and } \\
\text { receptor tyrosine kinase pathways, both of which are involved in cell differentiation and growth } \\
{[70] \text {. }}\end{array}$ \\
\hline PCDH11XY & $\mathrm{Xq} 21.3 / \mathrm{Yp} 11.2$ & Cell-surface adhesion molecules expressed predominantly in the brain $[18,39,71]$. \\
\hline MAGEA $11^{\mathrm{c}}$ & $\mathrm{Xq} 28$ & $\begin{array}{l}\text { Involved in the androgen and progesterone receptor signaling pathway. Involved in migration and } \\
\text { differentiation of cells in embryos and germ cells [72]. }\end{array}$ \\
\hline ARHGAP4 ${ }^{\mathrm{a}}$ & $\mathrm{Xq} 28$ & $\begin{array}{l}\text { Produces RHO GTPase-activating protein that plays a part in growth of axons and mobility of cells } \\
\text { during embryonic development }[40,48] \text {. }\end{array}$ \\
\hline $\mathrm{MECP}^{\mathrm{a}}$ & $\mathrm{Xq} 28$ & $\begin{array}{l}\text { Involved in the expression of DNA sequences that have been methylated. An epigenetic factor that } \\
\text { participates in chromatin folding and transcriptional regulation }[40,44] \text {. }\end{array}$ \\
\hline GPR50 & $\mathrm{Xq} 28$ & $\begin{array}{l}\text { Encodes a protein that can disrupt melatonin signaling. Also associated with neural development. } \\
\text { May be connected to neurotransmitter signaling and response to stress }[73,74] \text {. }\end{array}$ \\
\hline IRAK1 & $\mathrm{Xq} 28$ & Crucial to the IL-1 receptor signaling pathway $[40,49,50]$. \\
\hline SRY & $\mathrm{Y}$ & May be involved in dopamine regulation [53]. \\
\hline $\mathrm{RENBP}^{\mathrm{a}}$ & $\mathrm{Xq} 28$ & $\begin{array}{l}\text { Involved in the renin angiotensin system with production of angiotensin II, a neurotransmitter that } \\
\text { communicates with dopaminergic systems. Hypothesized to be important for normal thought } \\
\text { processes }[40,54,55] \text {. }\end{array}$ \\
\hline
\end{tabular}

${ }^{a}$ Candidate genes found through a genome-wide association study. ${ }^{\mathrm{b}}$ Candidates from genome-wide exome sequencing studies. ${ }^{c}$ Candidate genes from a genome-wide copy number variation analysis.

volvement of these genes in schizophrenia. They are part of a small class of genes that have homologies on both $\mathrm{X}$ and $\mathrm{Y}$. These are cell surface adhesion molecules expressed predominantly in the brain.
3. MECP2, a gene that is involved in the expression of DNA sequences that have been methylated. This gene is expressed in greater amounts in the brain than in other tissues in the body, and mutations in the gene 
have been associated with many neurodevelopmental disorders, including autism and schizophrenia [4042]. It is also associated with decreased brain cortical area in at least 2 studies [43, 44]. Additionally, MECP2 has recently been shown in animal models to be an integral component for GABA release from neurons [45]. Of note, GABAergic dysfunction has been long thought to be involved in the pathogenesis of schizophrenia $[46,47]$.

4. ARHGAP4 gene, specifically involved in producing the RHO GTPase activating protein. This protein plays a role in growth of axons and mobility of cells during development in utero. It is heavily present in the central nervous system during this period and was found to be a gene of interest for schizophrenia within the Xq28 region $[40,48]$.

5. IRAK1, another gene of interest, plays a role in the IL-1 receptor signaling pathway. Specific IL- $1 \beta$ receptor gene polymorphisms have been associated with an increased risk of schizophrenia $[40,49,50]$. IL- $1 \beta$ is also hypothesized to participate in immunological reactions involving infections in utero, which may then lead to deleterious effects on a developing neurological system $[40,51]$.

6. The SRY gene on the Y chromosome [52]. The gene is present on a limited number of dopaminergic neurons in the midbrain area and has been suggested to be involved in important processes involving dopamine regulation, i.e., catecholamine synthesis, in the midbrain in animal models [53]. Few, if any, studies have looked at this particular gene in psychosis or schizophrenia.

\section{The Unbiased Screening of the Genome}

Beginning in approximately 2007, a new concept became the major focus of the field of psychiatric genetics, that is, to perform large genome-wide association studies (GWAS) with very densely packed marker sets to find risk genes for all the major psychiatric disorders, including schizophrenia. One of the largest international research collaborations in psychiatry was formed during this time, the Psychiatric Genomics Consortium (PGC), and, ultimately, it has been able to perform GWAS of schizophrenia on over 100,000 individuals with the published results showing several risk variants of small effect, including some on the sex chromosomes [32,33]. The markers used to screen in GWAS generally cover the X chromosome, but not the $\mathrm{Y}$ chromosome, in a dense enough pattern to be able to perform a meaningful GWAS.
However, the first smaller GWAS of schizophrenia performed demonstrated some evidence of SNPs associated with the $\mathrm{X}$ chromosome in their top results $[13,30$, 31]. Wong et al. [40] performed a GWAS of schizophrenia in the Han Chinese population and also examined a group of selected candidate genes from prior studies and plausible biological pathways. In this series of studies, they found genome-wide significance for SNPs in the gene RENBP as well as in 2 other genes that have previously been associated with schizophrenia, ARHGAP4 and MECP2, all 3 of which are located on Xq28.

RENBP, renin-binding protein, is involved in the renin angiotensin system. This system has previously been thought to be involved in schizophrenia as well as other disorders [40, 54, 55]. Angiotensin II is a neurotransmitter that communicates with dopaminergic systems in the brain and is hypothesized to be important for normal thought processes $[56,57]$.

The first publication from the International Schizophrenia Consortium [32], later incorporated within the larger PGC (http://www.med.unc.edu/pgc/about-us/ about-the-pgc), interestingly, out of the SNP associations with $p<0.0001$, found 2 mapped to the $\mathrm{X}$ chromosome, one of which was XY homologous. In a later publication from this consortium [33], some loci on the X chromosome reached genome-wide significance and included 2 genes of interest involved in synaptic plasticity and function: NLGN4X on Xp21.3 and CNKSR2 on Xp22.12.

There are also some other intriguing recently published studies that suggest focusing back on examining the sex chromosomes. One is a large Swedish exome sequencing study on over 12,000 individuals, 4,877 with schizophrenia [58]. These authors, focusing on the presence of ultra-rare variants, found them to be significantly more frequent in people with schizophrenia than in the rest of the population. Most of the rare variants were concentrated in brain-expressed genes, disrupting the gene sequence, presumably altering protein structure. Most relevant is that the elevation in damaging ultra-rare mutations appeared to be mostly within X-linked genes for intellectual disability, including KDM5C (an H3K4 methylation eraser gene variant). There are other exome sequencing studies of schizophrenia showing an excess of variants in genes whose mRNAs are bound by the fragile X mental retardation protein (FMRP; [58-60]).

Similarly, the recently published large-scale copy number variation (CNV) analysis of the PGC data [61] also found some $\mathrm{X}$ chromosome associations. In this report of over 21,000 cases, CNVs were found in various locations throughout the genome, but also included 2 
significant duplications on Xq28 (one of which was in MAGEA11) and suggestive, although not significant, deletions on Xp21.2 (DMD). It is also interesting that a study of CNVs in Klinefelter's individuals [62] showed an overall increase in CNVs when compared with normal males or females, and half of the X-linked CNVs fell within regions encompassing genes. Most of these genes (90\%) escape $\mathrm{X}$ inactivation and are within the regions of $\mathrm{X}-\mathrm{Y}$ homology, particularly the pseudoautosomal region 1 (PAR1) and Xq21.31.

In summary, the role variants in genes on the sex chromosomes play in abnormal brain development, and thus in the risk for mental illnesses, is yet to be determined. The challenges that have prevented progress in understanding the effects of these genes are many and include the complex role $\mathrm{X}$ inactivation plays in gene expression and the manner in which homologous genes on both $\mathrm{X}$ and $\mathrm{Y}$ chromosomes contribute to gene expression. Future studies might clarify the significance of the sex chromosomes in schizophrenia by examining sequencing data on the sex chromosomes in multiplex families to identify loci shared by all affecteds within families [63], exploring these abnormalities across diagnoses and further exploring the candidate genes that have thus far been observed, particularly as they have emerged from the unbiased GWAS and CNV whole-genome screens. A combination of new sequencing techniques in multiplex families with a focus on sex chromosomes may ultimately move this notion from the "sex chromosome hypothesis" to the finding of genes of risk for schizophrenia and other disorders, as well as lead to a further understanding of the role of the sex chromosomes in brain development and maldevelopment at the molecular level.

\section{Statement of Ethics}

There are no ethical issues with the data reviewed in this article.

\section{Disclosure Statement}

The authors have no conflicts of interest for any of the information in this article.

\section{References}

1 DeLisi LE, Reiss AL, White BJ, Gershon ES: Chromosomal aberrations in schizophrenia. Schizophr Res 1988;1:277-281.

2 DeLisi LE, Friedrich U, Wahlstrom J, BoccioSmith A, Forsman A, Eklund K, Crow TJ: Schizophrenia and sex chromosome anomalies. Schizophr Bull 1994;20:495-505.

3 DeLisi LE, Crow TJ: Evidence for an X chromosome locus for schizophrenia. Schizophr Bull 1989;15:431-440.

4 Nielsen J, Fischer M: Sex-chromatin and sexchromosome abnormalities in male hypogonadal mental patients. Br J Psychiatry 1965; 111:641-647.

5 Trixler M, Kosztolányl G, Méhes K: Sex chromosome aberration screening among male psychiatric patients (author's transl). Arch Psychiatr Nervenkr (1970) 1976;221:273282

6 Polani PE: Abnormal sex chromosomes and mental disorders. Nature 1969;223:680-686.

7 Kaplan AR: Sex-chromatin variations in institutionalized females. I. Sex chromosome anomalies in hospitalized schizophrenics, adult prisoners, confined juvenile offenders, and noninstitutionalized volunteers. Recent Adv Biol Psychiatry 1966;9:21-27.

8 DeLisi LE, Maurizio AM, Svetina C, Ardekani B, Nierenberg J, Szulc K, Leonard J, Harvey P: Klinefelter's syndrome (XXY) as a genetic model for psychotic disorders. Am J Med Genet B Neuropsychiatr Genet 2005;135B:15-23.
9 Seeman MV: Gender differences in schizophrenia. Can J Psychiatry 1982;27:107-112.

10 Seeman MV: Sex and schizophrenia. Can J Psychiatry 1985;30:313-315.

11 Seeman MV: Women and schizophrenia. Medscape Womens Health 2000;5:2.

12 Abel KM, Drake R, Goldstein JM: Sex differences in schizophrenia. Int Rev Psychiatry 2010;22:417-428.

13 Goldstein JM, Cherkerzian S, Tsuang MT, Petryshen TL: Sex differences in the genetic risk for schizophrenia: history of the evidence for sex-specific and sex-dependent effects. Am J Med Genet B Neuropsychiatr Genet 2013;162B:698-710.

14 Crow TJ, DeLisi LE, Johnstone EC: Concordance by sex for psychosis is paternally inherited: evidence for a pseudoautosomal locus. Br J Psychiatry 1989;155:92-97.

15 Crow TJ: The continuum of psychosis and its genetic origins. The sixty-fifth Maudsley lecture. Br J Psychiatry 1990;156:788-797.

16 Crow TJ: A continuum of psychosis, one human gene, and not much else - the case for homogeneity. Schizophr Res 1995; 17:135145.

17 Crow TJ: A Darwinian approach to the origins of psychosis. Br J Psychiatry 1995;167: 12-25, erratum in Br J Psychiatry 1995;16: 414.
18 Crow TJ: The XY gene hypothesis of psychosis: origins and current status. Am J Med Genet B Neuropsychiatr Genet 2013;162B:800824 .

19 Skuse DH: X-linked genes and mental functioning. Hum Mol Genet 2005;14 Spec No 1:R27-R32.

$20 \mathrm{Xu}$ J, Disteche CM: Sex differences in brain expression of X- and Y-linked genes. Brain Res 2006;1126:50-55.

21 Collinge J, DeLisi LE, Boccio A, Johnstone EC, Lane A, Larkin C, Leach M, Lofthouse R, Owen F, Poulter M, Crow TJ: A pseudoautosomal locus for schizophrenia: molecular evidence from an analysis of sib-pairs. Br J Psychiatry 1991;158:624-629.

22 Laval S, Dann J, Butler RJ, Loftus J, Rue J, Leask SJ, Bass N, Comazzi M, Vita A, Nanko S, Shaw S, Peterson P, Shields G, Smith AB, Stewart J, DeLisi LE, Crow TJ: Evidence for linkage to psychosis and cerebral asymmetry (relative hand skill) on the $\mathrm{X}$ chromosome. Am J Med Genet B Neuropsychiatr Genet 1998;81:420-427.

23 Crow TJ, Poulter M, Lofthouse R, Chen G, Shah T, Bass N, Morganti C, Vita A, Smith C, Boccio A, Shields G, DeLisi LE: Male siblings with schizophrenia share alleles at the androgen receptor above chance expectation. Am J Med Genet B Neuropsychiatr Genet 1993;48 159-160. 
24 Crow TJ, DeLisi LE, Lofthouse R, Poulter M, Lehner T, Bass N, Shah T, Walsh C, BoccioSmith A, Shields G, Ott J: An examination of linkage of schizophrenia and schizoaffective disorder to the pseudoautosomal region (Xp22.3). Br J Psychiatry 1994;164:159-164.

25 DeLisi LE, Devoto M, Lofthouse R, Poulter M, Smith A, Shields G, Bass N, Chen G, Vita A, Morganti C, Ott J, Crow TJ: Search for linkage to schizophrenia on the $\mathrm{X}$ and $\mathrm{Y}$ chromosomes. Am J Med Genet B Neuropsychiatr Genet 1994;54:113-121.

26 Dann J, DeLisi LE, Devoto M, Laval S, Nancarrow DJ, Shields G, Smith A, Loftus J, Peterson P, Vita A, Comazzi M, Invernizzi G, Levinson DF, Wildenauer D, Mowry BJ, Collier D, Powell J, Crowe RR, Andreasen NC, Silverman JM, Mohs RC, Murray RM, Walters MK, Lennon DP, Hayward NK, Albus M, Lerer B, Maier W, Crow TJ: A linkage study of schizophrenia to markers within Xp11 near the MAOB gene. Psychiatr Res 1997;70:131143.

27 DeLisi LE, Shaw S, Sherrington R, Nanthakumar B, Shields G, Smith AB, Wellman N, Larach VW, Loftus J, Razi K, Stewart J, Vita A, Comazzi M, De Hurt M, Crow TJ: Failure to establish linkage on the $\mathrm{X}$ chromosome in 301 families with schizophrenia or schizoaffective disorder. Am J Med Genet B Neuropsychiatr Genet 2000;96:335-241.

28 DeLisi LE, Crow TJ, Davies KE, Terwilliger JD, Ott J, Ram R, Flint T, Boccio A: No genetic linkage detected for schizophrenia to Xq27-28. Br J Psychiatry 1991;158:630-634.

29 DeLisi LE, Wellman N, Stewart J, Smith AB, Churchman M, Crow TJ: A linkage disequilibrium study of markers within the pericentromeric region of the $\mathrm{X}$ chromosome. Am J Med Genet B Neuropsychiatr Genet 1999;88: 588-589.

30 Barr CL, Kennedy JL, Pakstis AJ, Castiglione CM, Kidd JR, Wetterberg L, Kidd KK: Linkage study of a susceptibility locus for schizophrenia in the pseudoautosomal region. Schizophr Bull 1994;20:277-286.

31 Kalsi G, Curtis D, Brynjolfsson J, Butler R, Sharma T, Murphy P, Read T, Petursson H, Gurling HM: Investigation by linkage analysis of the XY pseudoautosomal region in the genetic susceptibility to schizophrenia. Br J Psychiatry 1995;167:390-393.

32 International Schizophrenia Consortium: Common polygenic variation contributes to risk of schizophrenia that overlaps with bipolar disorder. Nature 2009;460:748-752.

33 Schizophrenia Working Group of the Psychiatric Genomics Consortium: Biological insights from 108 schizophrenia-associated genetic loci. Nature 2014;511:421-427.

34 Goldstein JM, Cherkerzian S, Seidman LJ, Petryshen TL, Fitzmaurice G, Tsuang MT, Buka SL: Sex-specific rates of transmission of psychosis in the New England high-risk family study. Schizophr Res 2011;128:150-155.
35 Bergen SE, Fanous AH and Walsh D, O'Neill FA, Kendler KS: Polymorphisms in SLC6A4, $\mathrm{PAH}, \mathrm{GABRB} 3$, and MAOB and modification of psychotic disorder features. Schizophr Res 2009;109:94-97.

36 Carrera N, Sanjuan J, Molto MD, Carracedo A, Costas J: Recent adaptive selection at MAOB and ancestral susceptibility to schizophrenia. Am J Med Genet B Neuropsychiatr Genet 2009;150B:369-374.

37 Sun J, Jayathilake K, Zhao Z, Meltzer HY: Investigating association of four gene regions (GABRB3, MAOB, PAH, and SLC6A4) with five symptoms in in schizophrenia. Psychiatr Res 2012;198:202-206.

38 Piton A, Gauthier J, Hamdan FF, Lafrenière RG, Yang Y, Henrion E, Laurent S, Noreau A, Thibodeau P, Karemera L, Spiegelman D, Kuku F, Dugay J, Destroismaisons L, Jolivet P, Côte M, Lachapelle K, Diallo O, Raymond A, Marineau C, Champagne N, Xiong L, Gaspar C, Rivière J-B, Tarabeux J, Cossette P, Krebs M-O, Rapoport JL, Addington A, De Lisi LE, Mottron L, Joober R, Fombonne E, Drapeau $P$, Rouleau GA: Systematic resequencing of Xchromosome synaptic genes in autism spectrum disorder and schizophrenia. Mol Psychiatry 2011;16:867-880.

39 Crow TJ: Schizophrenia as variation in the sapiens-specific epigenetic instruction to the embryo. Clin Genet 2012;81:319-324.

40 Wong EH, So HC, Li M, Wang Q, Butler AW, Paul B, Wu HM, Hui TC, Choi SC, So MT, Garcia-Barcelo MM, McAlonan GM, Chen EY, Cheung EF, Chan RC, Purcell SM, Cherny SS, Chen RR, Li T, Sham PC: Common variants on Xq28 conferring risk of schizophrenia in Han Chinese. Schizophr Bull 2014;40:777786.

41 Shibayama A, Cook EH Jr, Feng J, Glanzmann C, Yan J, Craddock N, Jones IR, Goldman D, Heston LL, Sommer SS: MECP2 structural and $3^{\prime}$-UTR variants in schizophrenia, autism and other psychiatric diseases: a possible association with autism. Am J Med Genet B Neuropsychiatr Genet 2004;128B:50-53.

42 Chahrour M, Jung SY, Shaw C, Zhou X, Wong ST, Qin J, Zoghbi HY: MeCP2, a key contributor to neurological disease, activates and represses transcription. Science 2008;320: 1224-1229.

43 Joyner AH, J CR, Bloss CS, Bakken TE, Rimol LM, Melle I, Agartz I, Djurovic S, Topol EJ, Schork NJ, Andreassen OA, Dale AM: A common MECP2 haplotype associates with reduced cortical surface area in humans in two independent populations. Proc Natl Acad Sci USA 2009; 106:15483-15488.

44 Colibazzi T, Wexler BE, Bansal R, Hao X, Liu J, Sanchez-Peña J, Corcoran C, Lieberman JA, Peterson BS: Anatomical abnormalities in gray and white matter of the cortical surface in persons with schizophrenia. PLoS One 2013;8:e55783.
45 Chao HT, Chen H, Samaco RC, Xue M, Chahrour M, Yoo J, Neul JL, Gong S, Lu HC, Heintz N, Ekker M, Rubenstein JL, Noebels JL, Rosenmund C, Zoghbi HY: Dysfunction in GABA signaling mediates autism-like stereotypies and Rett syndrome phenotypes. Nature 2010;468:263-269.

46 Costa E, Davis JM, Dong E, Grayson DR, Guidotti A, Tremolizzo L, Veldic M: A GABAergic cortical deficit dominates schizophrenia pathophysiology. Crit Rev Neurobiol 2004;16:1-23.

47 Nakazawa K, Zsiros V, Jiang Z, Nakao K, Kolata S, Zhang S, Zhang S, Belforte JE: GABAergic interneuron origin of schizophrenia pathophysiology. Neuropharmacology 2012;62:1574-1583.

48 Vogt DL, Gray CD, Young W: ARHGAP4 is a novel RhoGAP that mediates inhibition of cell motility and axon outgrowth. Mol Cell Neurosci 2007:36:332-342.

49 Sasayama D, Hori H, Teraishi T, Hattori K, Ota M, Iijima Y, Tatsumi M, Higuchi T, Amano N, Kunugi $\mathrm{H}$ : Possible association between interleukin- $1 \beta$ gene and schizophrenia in a Japanese population. Behav Brain Funct 2011;7:35.

50 Söderlund J, Schröder J, Nordin C, Samuelsson M, Walther-Jallow L, Karlsson H, Erhardt $S$, Engberg G: Activation of brain interleukin$1 \beta$ in schizophrenia. Mol Psychiatry 2009;14: 1069-1071.

51 Marx CE, Jarskog LF, Lauder JM, Lieberman JA, Gilmore JH: Cytokine effects on cortical neuron MAP-2 immunoreactivity: implications for schizophrenia. Biol Psychiatry 2001; 50:743-749.

52 Gillies GE, Virdee K, McArthur S, Dalley JW: Sex-dependent diversity in ventral tegmental dopaminergic neurons and developmental programing: a molecular, cellular and behavioral analysis. Neuroscience 2014;282:69-85.

53 Czech DP, Lee J, Sim H, Parish CL, Vilain E, Harley VR: The human testis determining factor SRY localizes in midbrain dopamine neurons and regulates multiple components of catecholamine synthesis and metabolism. J Neurochemistry 2012;122:260-271.

54 Kucukali CI, Aydin M, Ozkok E, Bilge E, Zengin A, Cakir U, Kara I: Angiotensin-converting enzyme polymorphism in schizophrenia, bipolar disorders, and their first-degree relatives. Psychiatr Genet 2010;20:14-19.

55 Crescenti A, Gassó P, Mas S, Abellana R, Deulofeu R, Parellada E, Bernardo M, Lafuente A: Insertion/deletion polymorphism of the angiotensin-converting enzyme gene is associated with schizophrenia in a Spanish population. Psychiatry Res 2009;165:175-180.

56 Jenkins TA, Allen AM, Chai SY, MacGregor DP, Paxinos G, Mendelsohn FA: Interactions of angiotensin II with central dopamine. Adv Exp Med Biol 1996;396:93-103.

57 Jenkins TA, Mendelsohn FA, Chai SY: Angiotensin-converting enzyme modulates dopamine turnover in the striatum. J Neurochem 1997;68:1304-1311. 
58 Genovese G, Fromer M, Stahl EA, Ruderfer DM, Chambert K, Landén M, Moran JL, Purcell SM, Sklar P, Sullivan PF, Hultman CM, McCarroll SA: Increased burden of ultra-rare protein-altering variants among 4,877 individuals with schizophrenia. Nat Neurosci 2016;19:1433-1441.

59 Purcell SM, Moran JL, Fromer M, Rudefer D, Solovieff N, Roussos P, O'Dushlaine C, Chambert K, Bergen SE, Kahler A, Duncan L, Stahl E, Genovese G, Fernandez E, Collins MO, Komiyama NH, Choudhary JS, Magnusson PK, Banks E, Shakir K, Garimella K, Fennell T, DePristo M, Grant SG, Haggarty SJ, Gabriel S, Scolnick EM, Lander ES, Hultman CM, Sullivan PF, McCarroll SA, Sklar P: A polygenic burden of rare disruptive mutations in schizophrenia. Nature 2014;506:185190.

60 Fromer M, Pocklington AJ, Kavanagh DH, Williams HJ, Dwyer S, Gormley P, Georgieva L, Rees E, Palta P, Ruderfer DM, Carrera N, Humphreys I, Johnson JS, Roussos P, Barker DD, Banks E, Milanova V, Grant SG, Hannon E, Rose SA, Chambert K, Mahajan M, Scolnick EM, Moran JL, Kirov G, Palotie A, McCarroll SA, Holmans P, Sklar P, Owen MJ, Purcell SM, O'Donovan MC: De novo mutations in schizophrenia implicate synaptic networks. Nature 2014;506:179-184.
$61 \mathrm{CNV}$ and Schizophrenia Working Groups of the Psychiatric Genomics Consortium: Contribution of copy number variants to schizophrenia from a genome-wide study of 41,321 subjects. Nat Genet 2017;49:27-35.

62 Rocca, MS, Pecile V, Cleva L, Speltra E, Selice R, Di Mambro A, Foresta C, Ferlin A: The Klinefelter syndrome is associated with high recurrence of copy number variations on the $\mathrm{X}$ chromosome with a potential role in the clinical phenotype. Andrology 2016;4:328334.

63 DeLisi LE: A case for returning to multiplex families for further understanding the heritability of schizophrenia: a psychiatrist's perspective. Mol Neuropsychiatry 2016;2:15-19.

64 Gao Q, McNally EM: The dystrophin complex: structure, function and implications for therapy. Compr Physiol 2015;5:1223-1239.

65 Wei YL, Li CX, Li SB, Liu Y, Hu L: Association study of monoamine oxidase $\mathrm{A} / \mathrm{B}$ genes and schizophrenia in Han Chinese. Behav Brain Funct 2011;7:42.

66 Scandaglia M, Lopez-Atalaya JP, MedranoFernandez A, Lopez-Cascales MT, Del Blanco B, Lipinski M, Benito E, Olivares R, Iwase S, Shi Y, Barco A: Loss of Kdm5c causes spurious transcription and prevents the fine-tuning of activity-regulated enhancers in neurons. Cell Rep 2017;21:47-59.

67 Shen YC, Tsai HM, Ruan JW, Liao YC, Chen $\mathrm{SF}$, Chen $\mathrm{CH}$ : Genetic and functional analyses of the gene encoding synaptophysin in schizophrenia. Schizophr Res 2012;137:14-19.
68 Wei J, Hemmings GP: A further study of a possible locus for schizophrenia on the $\mathrm{X}$ chromosome. Biochem Biophys Res Commun 2006;344:1241-1245.

69 Wei J, Hemmings GP: Searching for a locus for schizophrenia within chromosome Xp11. Am J Med Genet 2000;96:4-7.

70 Sandhu HK, Sarkar M, Turner BM, Wassink TH, Philibert RA: Polymorphism analysis of HOPA: a candidate gene for schizophrenia. Am J Med Genet 2003;123B:33-38.

71 Giouzeli M, Williams NA, Lonie LJ, DeLisi LE, Crow TJ: Protocadherin X/Y, a candidate gene-pair for schizophrenia and schizoaffective disorder: a DHPLC investigation of genomic sequence. Am J Med Genet B Neuropsychiatr Genet 2004;129B:1-9.

72 Park S, Sung Y, Jeong J, Choi M, Lee J, Kwon W, Jang S, Park SJ, Kim JY, Kim SH, Yoon D, Ryoo ZY, Kim MO: Critical roles of hMAGEA2 in induced pluripotent stem cell pluripotency, proliferation, and differentiation. Cell Biochem Funct 2017;35:392-400.

73 Ryan J, Carrière I, Ritchie K, Ancelin ML: Involvement of GPR50 polymorphisms in depression: independent replication in a prospective elderly cohort. Brain Behav 2015; 5:e00313.

74 Grunewald E, Kinnell HL, Porteous DJ, Thomson PA: GPR50 interacts with neuronal NOGO-A and affects neurite outgrowth. Mol Cell Neurosci 2009;42:363-371. 